\title{
Code Choice in Cameroon Creative Writing in English: A Case Study of The Immortal Seed by Tah Protus
}

\author{
Yepdia Leundjeu Walter* \\ University of Ngaoundere, Cameroon.
}

\begin{abstract}
*Corresponding Author: Yepdia Leundjeu Walter, University of Ngaoundere, Cameroon.
\end{abstract}
\begin{abstract}
This paper is a sociolinguistic study which examined code choice in Cameroon creative writing in English, notably The Immortal Seed by Tah Protus. It also investigated on the paralinguistic functions of language variation in the novel and the writers' concerns emerging from the multilingual writing techniques employed. The data collected were mainly corpus-based characterized by assorted language varieties singled out from the book the researcher perused. The study drew inspiration from Sumarsono (2009) and MyersScotton $(1993,1998)$ theoretical frameworks. The findings revealed that the writer, in the narrative process, intertwined English with miscellaneous linguistic codes to negotiate sundry social relationships and to hook readers. The narrator and characters alternated between codes: they mixed English with indigenous languages (Bafut language), lingua francas (pidgin-English, Fulfulde) and foreign languages (French, Spanish) to achieve functions such as sarcastic irony, humour, equivalence, loyalty, ethnicity, solidarity, explanation, clarity, imitation, snobbism, class and multilingual competence. Concerns underlying the writer's multilingual writing strategies include the language question in British Cameroon State institutions, language stereotypes and stigmatisation, the promotion of multilingual literacy, pacific coexistence, living together and social integration.
\end{abstract}

KEYWORDS: code choice, Cameroon creative writing, paralinguistic functions, multilingual literacy, living together, social integration.

\section{INTRODUCTION}

Code choice is a sociolinguistic phenomenon which is characteristic of bilingual and multilingual speakers, who in dialogic conversations, use two or more languages to negotiate personal relationships. This paper explores features of language choice in The Immortal Seed, a novel by Tah Protus. Also, it scrutinises the paralinguistic functions of selected codes and finally sorts out of the book the writers' preoccupations forming the basis of the discursive writing strategies used.

The Immortal Seed is a multilingual creative writing deploying heterogeneous linguistic choices which depict political, linguistic, social and cultural issues impacting the Cameroon society. The narrator and characters alternate between two or more codes which deserve attention. Specifically, they mix English with languages of wider communication (Pidgin English, Fulfulde), indigenous language (Bafut language), foreign languages (French, Spanish) or they use a substandard style to exchange.

Based on the above problem, the following research questions were devised:

1. What are the features of code choice in The Immortal Seed?

2. What are the paralinguistic functions of the choices made?

3. What are the writer's concerns emerging from the hybrid style used in the discourse?

This study is significant for many regards:

First, this sociolinguistic research shows how multilingual choices work in African creative writing in English, in Cameroon works of art in particular. Secondly, it demonstrates how language variation contributes to the expression of political, linguistic, social, cultural and stylistic concerns. Finally, the study indicates how the use of multilingual codes in literature may promote multilingualism, living together and social integration.

This research work begins with the review of literature considering aspects such as African creative writing in multilingual communities including code choice and the review of previous works. Next is 
the research design, which looks at the theoretical framework, the method of data collection and analysis. Further, the results of findings are presented and discussed. Finally, the writer's preoccupations raised by linguistic choices are identified and suggestions for further research made.

\section{LITERATURE REVIEW}

Aspects under consideration in this section are the situation of African creative writing in multilingual communities, code choice and review of related works.

\subsection{African Creative Writing in Multilingual Communities}

Poetry, drama and prose are fiction creative writings with idiosyncratic characteristics. They differ in terms of writing techniques and style. Postcolonial African creative writers as opposed to western writers are usually confronted with the question of language choice dilemma to address their audience: should they write exclusively in English or should they mix English with indigenous or local dialects? Ukam (2018) brought to light a serious argument among African critics about which language (s) would be authentic in creative writing: colonial languages which serve as lingua franca, or the native indigenous languages. While some postcolonial writers like Ngugi have argued for the authenticity and a return in writing in indigenous African languages, avoiding imperialism and subjugation of the colonisers, others like Achebe were in the opinion that the issue of language should not be the main reason in defining African literature: any language could be adopted to portray the lifestyles and peculiarities of Africans.

Ukam (2018) pointed out that although it is authentic to write in one's native language so as to meet the target audience, yet many Africans received their higher education in one of the colonial and/or European languages; and as such, majority did not know how to write in their native languages. Rather, they wrote in the imposed colonial languages in order to meet a wider audience. Not until one or two major African languages are standardised, taught in schools, acquired by more than 80 per cent of Africans and used as common languages, the colonial languages would forever continue to have a greater influence in writing African literature. The researcher in her development concluded that Africans should have one or two major African languages standardised, serving as common languages; also African literature should be written in both colonial and African languages in order to avoid the language debate by creative African writers.

The complexity of the sociolinguistic landscape of African countries, essentially made up of bilingual and multilingual speech communities, where colonial languages cohabitate with indigenous languages, gives African writers a multitude of choices which gives room to innovative writing techniques which tally with their preoccupations and the desired effects they want to produce on their audience. They draw from the linguistic repertoire of speech participants to expose the ills of their society. Their main concerns are generally about binary and antagonistic themes such as colonialism vs self-autonomy; dictatorship vs democracy; oppression vs peace; tradition vs modernism; masculinity vs feminism; conventional churches vs new religious trends, to name the few. While expressing those burning and thorny issues of their time, which mirror the cosmology and the landscape of their society, they mingle English with local languages and foreign languages in their train of speech; they switch from one code to another to negotiate personal relationships.' Chinua Achebe was one of the post-colonial writers, who in his creative works, successfully mixed English with Ibo language to reveal the contradictions of the Nigerian society which hardly conciled traditional values with western civilization as it is the case with Obi Okwonko. Interestingly, Cameroon English writers like John Kemngong Kengasong, Bole Butake, Bate Besong, Tanyi-Tang, Charles Alobwed'Epie, Tah Protus, the list is not exhaustive, also drew inspiration from their local culture to spice their writing. Carefully selected characters were given roles and languages which match their age, gender, social status and occupations. Such sociolinguistic choices play functional roles which mark identity, ethnicity, class, gender, distance, brotherhood, solidarity, humour, irony, sarcasm, etc.

\subsection{Code Choice}

For the understanding of this work, it is useful to define the word 'code' before elaborating on the compound 'code choice'. 'Code' is viewed by Wardhaugh (2010:98) as 'a particular dialect or language one chooses to use on any given occasion and the communication system used between two 
or more parties'. Thus, code is the language system used by a speaker to communicate with when need arises.

Subsequent to the above definition, code choice is defined by Genesee (1982) as a speaker's decision of which code to use in a given utterance, to what extent the different codes are to be used. Depending on the sociolinguistic and conversational context, a speaker's code choice may be unexpected and noticed by other speakers, and is likely to affect other speaker's subsequent code-choice. In other words, code choice occurs when speakers draw from their language repertoire the language which best suits communicative situations they face and the relationships they want to negotiate. Speakers may accommodate to each other's code choice, positively and negatively.

Sumarsono (2009:201) distinguished three kinds of language choice in the sociolinguistic field which are: code-switching, code-mixing and variation in the same language, which are going to be elaborated in turn. To start with, Bullock and Toribio (2009: xii) defined code-switching as "the alternating use of two languages in the same stretch of discourse by a bilingual speaker". Extensively, Romaine (1992:110) viewed it as "the use of more than one language, variety or style by speaker within an utterance or discourse, or between different interlocutors or situations". Overall, codeswitching occurs when more than one language is used in a conversation.

Many sociolinguists provided differing perspectives regarding code-switching. Poplack in Romaine (1995:122-123), identified three main types of code-switching which are:

1. Tag switching, which is simply the insertion of a tag in one language in an utterance, which is entirely in the other language.

2. Inter sentential switching, which involves a significant amount of syntactic complexity and conformity to the rules of both languages; therefore speakers performing this kind of switching are usually fairly proficient in the participating languages.

3. Intra sentential switching, which refers to the switching that occurs inside the same clause or sentence which then contains elements of both languages.

Alternatively, Wardhaugh \& Fuller (2015) distinguished two types of code-switching such as situational and metaphorical. Situational code-switching occurs when the languages used change according to the situations in which the speakers find themselves: they speak one language in one situation and another in a different one. More importantly, they switch for clearly reasons such as topic and discussion. What is observed is that one variety is used in a certain set of situations and another in an entirely different set (Wardhaugh \& Fuller, 2015:98). Besides, the change of language in conversation should be done for specific reasons or intentionally. Conversely, metaphorical situation has an affective dimension to it: the choice of code carries symbolic meaning, that is, the language fits the message. Code-switching in this context is done to show solidarity. This is illustrated in a quote attributed to Charles V, the Holy Roman Emperor, which indicates attitudes about certain languages being holy, the language of love or male solidarity, or crude or bestial: 'I speak Spanish to God, Italian to women, French to men, and German to my horse.' (Wardhaugh \& Fuller, 2015:98).

Code-mixing also known as intra sentential code-switching or intra sentential code-alternation as opposed to code-switching occurs when speakers use two or more languages below clause level within one social situation. Muysken (2000:1) utilised the term code -mixing to show "all situations where lexical things and linguistic components from two dialects show up in one sentence". The sociolinguist divided code-mixing into three main types:

1. Insertion (word/phrase)

The process of code mixing is conceived here as borrowing.

\section{Alternation}

Code-mixing is viewed here in terms of capability or equivalence of the language involved at the switch point.

\section{Congruent lexicalization (dialect)}

The notion of congruent lexicalization underlies the study of style shifting and dialect/standard variation rather than bilingual language use proper. For example, "hey, how are you? I'm Sam. Senang bertemu anda. Nice to meet you. 
To end, variation in the same language refers to shift in style between formal and informal choices. Speakers may decide to use the formal or informal style of the same language depending on participants, the context or the purpose of communication. According to Halliday (1989:44), there are two main types of variation in language, social and functional. Dialects are characterised by social or regional variation, whereas register concerns functional variation.

\subsubsection{Social factors affecting code choice}

Certain social factors account for the choice of particular varieties. Some relate to the users of language (participants) while others relate to its uses (the setting, the topic, the function) Holmes (2013:9) identified four social factors which influence language choice. She cautioned that not all were relevant in any particular context but they could be grouped in ways which are helpful. Those factors are:

\section{The participants:}

(a) who is speaking and

(b) who are they speaking to ?

2. The setting or social context of the interaction: where are they speaking?

3. The topic: what is being talked about?

4. The function: why are they speaking?

The sociolinguist argued that when both participants shared more than one variety, then other factors would contribute to the appropriate choice such as:

1. The social distance dimension concerned with participant relationships. How well do they know each other, i.e. what is the social distance between the participants? Are they strangers, friends, brothers?

2. The status dimension concerned with participant relationships.

3. The formality dimension relating to the setting or type of interaction.

4. The function dimension or goal of the interaction. What is the language being used for? Is the speaker asking a favour or giving orders to someone?

Holmes (2013:22-23) in addition to the factors discussed above added that domain is a number of such typical interactions that has been identified as relevant in describing patterns of code choice in many communities, such as family, friendship, religion, education, employment and administration.

\subsubsection{Reasons for code choice}

Various reasons could explain why speakers switch from one code to another. Many researchers discussed the major purposes researched by participants in conversation while they change language. Holmes (2013) mentioned that a speaker might shift to another language as a signal of group membership and shared ethnicity within an addressee. Code-switching could be used to express solidarity between people from different or same ethnic groups.

Sometimes, speakers tend to use different languages to imply a certain social status or to distinguish themselves from other social classes. Other reasons that have been found to prompt code switching are to sound 'elitist or stylish' (Shabt, 2007). (Auer, 2002) says that code-switching carries a hidden prestige which is made explicit by attitudes. Also, Al-Khatib (2003) says in a research she conducted that speakers may use code-switching 'to show power over the less powerful'. Suleiman (1999) remarked that the phenomenon of code-switching is very common and is looked upon as something prestigious and a sign of education and competence in more than one language.

Topic or subject of the conversation is considered another important reason that leads a multilingual speaker to code-switch. Holmes (2013) says on the issue of code-switching according to the topic that 'people may switch code within a speech event to discuss a particular topic'. Thus, speakers may tend to use more than one language within one same utterance according to the topic. In many situations, a bilingual may tend to talk about one certain topic in a language rather than another. 
Speakers might also engage in divergent speech, in which an individual person emphasises the social distance between himself and other speakers by using speech with linguistic features characteristic of his own group.

Shifting choice equally occurs in affective functions. Speakers may switch codes to express happiness, excitement, anger, sadness, and many other feelings. We can easily realise that most multilingual speakers use code switching to express a sudden or surprising feeling such as happiness or anger.

Lastly, language choice is also done for rhetorical reasons (Holmes, 2015). Code-switching is often used in speech and rhetoric, in order to either attract attention or to persuade an audience.

\subsection{Review of Previous Works}

In the research work entitled "Pidgin in creative works in English in Cameroon", Kouega \& Aseh (2017) described the use of Pidgin in creative works in English in Cameroon, with the focus on the forms that this language took in the works, the types of characters who were made to speak this language, and the functions that this language played in these works. The data comprised three plays such as Beast of no nation by Bate Besong, Bethrotal without libation by Bole Butake and My bundle of joy by Tanyi-Tang and two novels, namely The lady with the beard by Charles Alobwed'Epie and The widow's might by Nkemngong Kengasong, all published between 2000 and 2006 by experienced writers who had a good command of English and yet made their characters speak in Pidgin. The analysis showed that Pidgin in the corpus took the form of individual lexemes like salaka (libation, sacrifice) and relatively short utterances like This sun fit kill man (This sun is so hot that it can kill someone.). The characters who spoke Pidgin in these literary works were generally low-ranking and rural people, illiterates and other people who were hardly looked up to in the Cameroonian society. Finally, Pidgin helped writers to realise some stylistic effects such as variations on the scale of formality, with English being used when addressing a superior person and Pidgin when addressing an inferior person. Most importantly, creative writers reproduced in their works what was observed in the Cameroonian society and this could be regarded as a formal way of enhancing their readers' plurilingual competence.

Unlike researchers above, Sokeng, P.C. (2018) in her work entitled "Code-switching "as a Bilateral Tool" in Cameroonian ESL/EFL Classrooms" investigated on how and why teachers and Francophone students used code-switching in their ESL/EFL classrooms in a French/English bilingual department. The study involved ten randomly selected bilingual lecturers and 219 students. Data were collected through questionnaires, semi-structured interviews, interviews and classroom observations. The findings revealed that code switching was employed by both lecturers and students to perform various functions in the ESL classroom. It was observed that lecturers, against their will, used code-switching mainly to translate difficult notions and to explain part(s) of the lesson students had not understood check for comprehension, to organise classroom tasks, to maintain discipline and structure lesson, to correct pronunciation, to provide praise/feedback/personal remarks about students' performance, to encourage the participation of students in classroom activities, to reduce the anxiety of students and increase their motivation, and to build or strengthen interpersonal relationships between the teacher and students. Code switching was used by students as a learning strategy to compensate for their limited competence in the target language though they preferred a minimum use of it.

This work departs from the above studies as it focuses on a Cameroon creative writing in English which makes use of multilingual choices in the literary discourse not only for linguistic or stylistic purposes but also to enhance multiliteracy, living together, pacific coexistence and social integration.

\section{RESEARCH DESIGN}

The theoretical framework, the method of data collection and analysis are the core of this section.

\subsection{Theoretical Framework}

Sumarsono (2009) language choice theory and Myers-Scotton $(1993,1998)$ markedness model were used as theoretical paradigms.

Summarsono distinguished three language choice types in sociolinguistics such as: code-switching, code-mixing and variation in the same language discussed in section 2.2. 
Myers-Scotton (1998:18) model argues that there is more than one way of speaking in almost every speech community. No community is without at least two different speech styles. In many communities, more than one language is spoken and often more than one dialect of a language is spoken. These different styles, languages and dialects are typically associated with different social groups or contexts. Not everyone in the community has complete command of all the varieties in the community's linguistic repertoire, and not everyone uses the varieties with the same frequency (Myers-Scotton 1998:18). Markedness, according to Myers-Scotton (1998: 4), relates to the choice of one linguistic variety over other possible varieties. The speaker-hearer has the option of choosing what may be considered marked choices to convey certain messages of intentionality. The markedness model stipulates that the major motivation for variety in linguistic choices in any given community is the possibility of social-identity negotiations (Myers-Scotton 1993:111). Negotiations play an important role in any given interaction because it is a dynamic enterprise with at least two sides, without a foregone conclusion. Therefore, what the speaker provides is a presentation of self.

All linguistic codes or varieties come to have social and psychological associations in the speech community in which they are used. Given these associations, the use of a particular code is viewed in terms of the marked versus the unmarked opposition in reference to the extent its use matches community expectations for the interaction type. In other words, what community norms would predict is unmarked; what the community norms would not predict is marked (Myers-Scotton 1998: 5). The Markedness Model uses the marked versus unmarked distinction as a theoretical construct to explain the social and psychological motivations for making one code choice over another. As part of their innate language faculty, all language users have a predisposition to view linguistic codes as more or less marked or unmarked, given the social and intellectual context. Therefore, all people have the competence to assess linguistic codes in these terms (Myers-Scotton 1998: 6).

\subsection{Method of Data Collection and Analysis}

Tah Protus is the author of Immortal Seed published in 2015. Now of late, he was one of the promising emerging English-speaking Cameroonian writers. He was a High School teacher of English Language and Literature who won the 2011 Eko Prize Award-winning Novel. His publications included: Tortoise and the Jungle Folk, two short plays, A tale of AIDS, Immortal Seed, a three-level poetry course, Beginning Poetry, a set of ten children's story books, and a critical work, Mastering Literature in English. He had also a number of film scripts, notably, Beyond Repair, The Ordeal of the Eighth day, the Dream and Dividends of Fate. He died in February 23, 2018.

The data for this study largely come from both primary and secondary sources. The primary sources include the corpus of the book under scrutiny while secondary sources include written materials. Bafut and Fulfulde lexemes or utterances gathered from The Immortal Seed were translated by resource people of the speech community concerned.

The Immortal Seed is divided into twenty eight chapters. Passion, greed, crime and tradition are interwoven themes which keep the reader spellbound till the last page of the book.

The method of data analysis used is descriptive and interpretative. Extracts of code choice are sorted out, categorised, classified into tables and analysed accordingly.

\section{FindingS AND Discussions}

The findings revealed that The Immortal Seed outlined three types of code choice, namely codeswitching, code-mixing and variation in style with multifaceted functions and perspectives. Each type is presented and discussed alternately.

\subsection{Code-switching}

Protus creative work under analysis offers various patterns of code-switching presented as follows: French $\rightarrow$ English; English $\rightarrow$ Fulfulde and English $\rightarrow$ Bafut language.

\subsubsection{French $\rightarrow$ English patterns}

Four instances of French-English code-switching patterns are fished out of the novel as shown by Table 1 below: 
Table1. Code-switching: French $\rightarrow$ English patterns

\begin{tabular}{|l|l|}
\hline Number & Extracts \\
\hline 1 & $\begin{array}{l}\text { The waiting officers immediately began to shout orders at the recruits as though they had had } \\
\text { prior police training: } \\
\text { 'Garde-à-vous! Atta-a-a-a-a-n-sssion!' Constable Akono bellowed from behind dark eye glasses. } \\
\text { Amidst giggling and stifled yawns, the recruits tried as best they could to execute the orders. } \\
\text { 'Into-o-o-o two lines, } a \text {-a-aligné!' the constable ordered with a French accent (p.6). }\end{array}$ \\
\hline 2 & $\begin{array}{l}\text { Amid giggling, the recruits jumped and swung their hands upwards, sideways, upwards and } \\
\text { down, in tune with the frenchified version of the chant. They wished they could put down their } \\
\text { heavy sacks. } \\
\text { 'Arrêtez!' Sergeant Atangana barked. (p.8) }\end{array}$ \\
\hline $\begin{array}{l}\text { There was an assortment of articles on the table - phials, a make-up kit, envelopes with different } \\
\text { writings, two name cards: Lawyer Ngome and Mr Eyombo's, address cards, a packet of cigarette, } \\
\text { etc. It was the packet of French cigarettes that knocked the lid off the pot. } \\
\text { 'You smoke?' Tebene asked. } \\
\text { 'Non! She blurted out, shuddering. } \\
\text { 'So where are these from?' he asked, picking up the packet of cigarettes and two address } \\
\text { cards (p.185) }\end{array}$ \\
$\begin{array}{l}\text { 'Repos!' the superintendent ordered. Assi brought his right hand down from his temple and } \\
\text { slapped it noisily by the outward side of his right thigh. } \\
\text { 'Afternoon, sir!' he said. } \\
\text { 'Afternoon, returned the boss. (p.223) }\end{array}$ \\
\hline 4
\end{tabular}

In compliance with Table1, extract 1 exhibits a bilingual dialogue where Inspector Akono concurrently gives instructions to the new recruits in the police forces in both French and English with a comical undertone. He initiates his speech in French then switches medially to English and rounds off his command in French. In the first order, he firmly instructed his colleagues in French to put their right hand up on their temple saying 'Garde-à-vous! Attention!' while in the second order, he required them to line up using the French lexeme 'aligné!'

In the second extract, French is also invited in Sergeant Atangana's talk. He barked the word 'Arrêtez!' as quoted by the writer. There is multimodality in this context since the narrator starts the report in English and switches to French to introduce Sergeant Atangana speech, hence codeswitching.

Moreover, the third extract showcases a bilingual dialogue between Tebene and his girl friend Eposi, where Eposi is asked in English if she smokes but she denies it adamantly uttering the French ergative 'Non!'.

Lastly, extract four showcases another instance of bilingual code-switching between Mr Agwe, the superintendent of police, and Inspector Assi. The police boss, in reply to the salute of his subordinate, ordered him 'Repos', meaning that he should put down his right hand down from his temple. Inspector Assi executed the order then greeted the boss in English and the latter replied in English too.

\subsubsection{English $\rightarrow$ Fulfulde patterns}

Among the linguistic choices operated by Tah Protus, Fulfulde is not exempted. Fulfulde is a dialect spoken by the Fulani people disseminated in the West and Central Africa. In Cameroon, the dialect is dominant in the Far North, the North and the Adamawa, where it is used as a lingua franca.

Table2. Code-switching: English $\rightarrow$ Fulfulde

\begin{tabular}{|c|c|}
\hline Number & Extracts \\
\hline 5 & $\begin{array}{l}\text { Bi asked the kids to teach her a song. There was much giggling and coughing. It took time to } \\
\text { decide what song to teach. Every child wanted to teach a song. In the end it was Adama who } \\
\text { taught a song. The lyrics and melody were easy to follow. The song was not new to the children } \\
\text { for as soon as Adama sang each solo-line the kids spontaneously sang the chorus. In the cool } \\
\text { windy night, one could hear: } \\
\text { Solo: A yidi goro? } \\
\text { Chorus: Ey, mi yidi goro, } \\
\text { Mi nyame goro. } \\
\text { Solo: A yidi mbaiji? } \\
\text { Chorus: Ey, mi yidi mbaiji, }\end{array}$ \\
\hline
\end{tabular}




\begin{tabular}{|c|c|}
\hline & $\begin{array}{l}\text { Mi nyame mbaiji. } \\
\text { Solo: A yarai kosam? } \\
\text { Chorus: Ey, mi yarai kosam, } \\
\text { Mi nyame kosam. } \\
\text { Solo: } \quad \text { A yidi marore? } \\
\text { Chorus: Ey, mi yidi marore, } \\
\quad \text { Mi nyame marore. } \\
\text { Solo: A yidi gaori? } \\
\text { Chorus: Ey, mi yidi gaori, } \\
\quad \text { Mi nyame gaori. (p.173) }\end{array}$ \\
\hline 6 & $\begin{array}{l}\text { As they resumed their seats, the Fon took up his speech again. } \\
\text { 'To our Mbororo friends, we say welcome to this palace, your palace. We have many } \\
\text { issues to talk about hereafter. For today, the one thing we have to tell all the Mbororo brethren is } \\
\text { that they must acquire land certificates and settle permanently wherever they are. All Mbororos } \\
\text { and people of Dik must acquire birth and marriage certificates. The SDO himself is here with all } \\
\text { his collaborators, ready to assist you.' He turned and looked at the senior government official who } \\
\text { gave no approval. To him, the young Fon was giving out just the right message. He was sure he } \\
\text { would make a better collaborator than his predecessor. } \\
\text { 'We invite all Medik to reconcile with themselves and with one another. We invite all } \\
\text { Medik to embrace their Mbororo neighbours and live with them as brothers and sisters. Dik will } \\
\text { not complete without its Mbororo community.' } \\
\text { The Mbororo community rose like one man, waving their horsewhips, swords and other } \\
\text { gadgets in the air, shouting: 'Alarene!Alarene! Alarene!Alarene!' (p.244) }\end{array}$ \\
\hline 7 & $\begin{array}{l}\text { Sadatu rose to go, promising to come for them later that afternoon. } \\
\text { 'But don't say anything to anybody yet,' Tebene instructed. 'See you in the afternoon! } \\
\text { 'Insha Alla!' Sadatu said, galloping away." (p.205) }\end{array}$ \\
\hline
\end{tabular}

As shown by Table 2 above, extract 5 represents a case of code-switching where the narrator reports an event in English and thereafter gives the floor to Adama, a Fulani girl, to intone a song, on Bi's request, in Fulfulde. Though she sang in Fulfulde, the melody was known by the children around her. As a matter of fact, the song is about a series of questions asking if the audience likes a particular food. The audience responds that they like the type of food and that they eat it as delineated by the translated version of the song below:

Solo: Do you like kola nuts?

Chorus: Yes, I like kola nuts, I eat kola nuts.

Solo: Do you like cassava?

Chorus: Yes, I eat cassava, I eat cassava.

Solo: Do you drink milk?

Chorus: Yes, I drink milk,

Solo: Do you like cassava?

Chorus: Yes, I like cassava, I eat cassava.

Solo: Do you like corn?

Chorus: Yes, I like corn, I eat corn.

Extract 6 is another set of bilingual code-switching between the Fon and the Mbororos. In the queen language, the Fon enjoined the people of Medik to reconcile themselves and to cohabitate peacefully with their Mbororo counterparts, who are their neighbour. The Mbororos happily welcomed the idea with words of blessing: 'Alarene!Alarene! Alarene!Alarene!' which means 'May God have mercy on you.'

The last bilingual dialogue in English $\rightarrow$ Fulfulde puts into play a character called Tebene who takes leave of Sadatu in English who in return replies in Fulfulde as follows: 'Insha Alla!' which signifies "God willing." 


\subsubsection{English $\rightarrow$ Bafut language patterns}

Bafut language is spoken in the North West Cameroon by Bafut people. Below are some of the extracts highlighting interchanges mingling English with Bafut language in Table 3 below:

Table3. Code-switching: English $\rightarrow$ Bafut language

\begin{tabular}{|c|c|}
\hline Number & Extracts \\
\hline 8 & $\begin{array}{l}\text { After this first round, Ben-Tasi officially began the meeting. } \\
\text { 'I thank God the almighty, the God of Techwi, our first father, the God of all our fathers } \\
\text { that have gone before, for bringing us safely together and making this day possible. It has been } \\
\text { my greatest desire for us to meet as a family this way, one day. Here we are today. Without the } \\
\text { one above, we could not have been here.' } \\
\text { 'Ayene!' the assembly concurred. } \\
\text { At that instant, a smooth female voice immediately intoned a solo from the corner and the } \\
\text { whole house cheerfully joined in the chorus: } \\
\text { Solo: Mbe ye'e ti kweri kiy yire Yaweh! } \\
\text { Chorus: Yaweh wo neme-wa nga nom-zoh. } \\
\text { Solo: Mbe ye'e ti kweri kiy yire Yaweh! } \\
\text { Chorus: Yaweh wo neme-wa nga nom-zoh. } \\
\text { A-ayene, a-ayene, a-ayene, a-ayene, } \\
\text { Yaweh wo neme-wa nga nom-zoh. (p.83) }\end{array}$ \\
\hline 9 & $\begin{array}{l}\text { 'The Fon has sworn that he will not sleep until the boy's head and the girl's buttocks are brought } \\
\text { to him,' the man confirmed. } \\
\text { 'Kwi'h-foh nitu'! Aaah?' the woman exclaimed and immediately took off. (p.128) }\end{array}$ \\
\hline 10 & $\begin{array}{l}\text { 'We are aware,' Fon Mbezuboh went on, unaware of the latent fears in the minds of some of } \\
\text { his white guests, 'that in the past few days, we must have stepped on the toes of people who } \\
\text { might have stretched their legs out simply for relaxation. We did not know our way then. We ask } \\
\text { for pardon.' } \\
\text { 'Mbeh! Chamfoh! Ngi-Nyam!' the people echoed. (p.246) }\end{array}$ \\
\hline 11 & $\begin{array}{l}\text { 'If you believe in Jesus,' the pastor resumed, 'nothing can happen to you which he does not } \\
\text { allow. God made his creatures for happiness, not for sadness. Happiness is your lot from God. } \\
\text { Believe in Jesus, brother! Tell him you love him! Confess your sins to him and he will reveal his } \\
\text { miracles to you.' } \\
\text { 'Amen!' answered Akwen who appeared to be inspired, 'Holy Ghost fire, come down!' she } \\
\text { prayed. 'Rain your miracles on us in the most holy name of Je-e-esus, the only son of the living } \\
\text { God. Arama-arama kakulaka. Gamada gagomo rutundata. Amatata baya soloko adama. } \\
\text { Tatimatu adamaya...Gamada gagomo rutundata. Amatata baya soloko adama. Tatimatu } \\
\text { adamaya Arama-arama kakulaka. Ramada...'p.163 }\end{array}$ \\
\hline
\end{tabular}

The conversation in extract 8 of the above table puts together the Fon, named Ben-Tasi, presiding a meeting with his community. In his preamble in English language, he praises the Gods for having gathered them and made the day possible. In return, the assembly answered by 'Ayene' in Bafut language which means 'let it be so'. Afterwards, a female voice emerged from the group and intoned a song in Bafut language which the whole assembly cheerfully sang. The following lines are the translated version of the song:

Solo: Let's sing and praise the Lord.

Chorus: God is taking care of us.

Solo: Let's sing and praise the Lord.

Let it be so.

Let it be so.

Let's sing and praise the Lord.

In extract 9, the Fon is determined to punish two young villagers who have broken the rules of the clan; they fornicated so they should be punished. A woman in alignment exclaimed in Bafut 'Kwi' $h$ foh nitu'! Aaah?', to express her exasperation.

Extract 10, shows a bilingual dialogue where the Fon talks to his people in English while the assembly reply in Bafut language: 'Mbeh! Chamfoh! Ngi-Nyam!', asking for forgiveness for the harm the people of Dik might have done to the white guests. 
The last extract presents a pastor and a faithful in church, in a prayer session. Akwen starts her prayer in English and switches to a garbling and confused language. Even her husband Assi "could not understand the strange language she was speaking hysterically, and why she was dancing so frantically, eyes tightly shut, with hands outstretched.", the narrator reported (p.163).

\subsection{Code-Mixing}

In addition to code-switching, the exchanges collected from Protus book display code-mixing features, where the novelist blends English with Pidgin English, Bafut language with Fulfulde, to spice his writing. Two features of code-mixing were uncovered, namely alternation and borrowing.

\subsubsection{Alternation}

Alternated utterances include Pidgin mixed with English or English combined with Pidgin and French.

\section{$>$ Pidgin $\rightarrow$ English/English $\rightarrow$ Pidgin patterns}

Five extracts of Pidgin English code selection were sorted out from the novel.

Table4. Code-mixing: Pidgin $\rightarrow$ English/English $\rightarrow$ Pidgin patterns

\begin{tabular}{|c|c|}
\hline Number & Extracts \\
\hline 12 & $\begin{array}{l}\text { The bemused recruits fell in line and began to march forward into the strange campus in spite of } \\
\text { their fatigue. Nobody dared disobey after what the Superintendent Essono had nearly done to } \\
\text { their mate. They simply marched in, wondering what a linguistic ordeal their training could be. } \\
\text { 'Gorr may mah...two, sing!' intoned Inspector Medou. } \\
\text { The recruits recognized the melody and took up the notorious song which they had sung } \\
\text { frequently during march past practice back in primary school. } \\
\text { God made man, } \\
\text { Man made woman, } \\
\text { Woman made Satan, } \\
\text { Satan spoilt the world. } \\
\text { Fire!" (p.6) }\end{array}$ \\
\hline 13 & $\begin{array}{l}\text { 'I ghimemba', Inspector Medou intoned anew. The recruits automatically switched to the new } \\
\text { song. } \\
\qquad \begin{array}{l}\text { I remember when I was a soldier, } \\
\text { I remember how I marched under rain, } \\
\text { I remember how I loved my khaki, } \\
\text { I remember when I was a soldier... (p.7) }\end{array}\end{array}$ \\
\hline 14 & $\begin{array}{l}\text { The officers strolled to the midpoint of the line, conferred for a while, then turned and faced the } \\
\text { recruits. Sergeant Atangana took over command. } \\
\text { 'On the spot, ma-a-ark tam! Lef-rize! Biafré! Lef-rize!' Angléfu!' Then, 'By the right, one } \\
\text { tam, halt!' he ordered. } \\
\text { With a cloudy trampling of right legs, the marching came to an abrupt end. 'Le-e-e-e-f } \\
\text { torn!' Superintendent Atangana commanded. (p.7) }\end{array}$ \\
\hline 15 & $\begin{array}{l}\text { The recruits turned left and found themselves facing the president officers. Superintendent } \\
\text { Atangana handed over command to Constable Akono. } \\
\text { 'Ever-y-y-y-y bodi! Constable Akono ordered in a hoarse voiced, 'Stresh out your hans } \\
\text { sadwere! Make show you no tosh you voizin!'"' (p.8) }\end{array}$ \\
\hline 16 & $\begin{array}{l}\text { 'Jom up ich tam you henz go up! Ordered Sergeant Atangana as he took over command of } \\
\text { the drill: } \\
\text { Upwere, sarewere, upwere, dong! } \\
\text { Upwere, sarewere, upwere, dong! } \\
\text { Upwere, sarewere, upwere, dong! (p.8) }\end{array}$ \\
\hline
\end{tabular}

In accordance with Table 12, extract 11 is about Inspector Medou, who uses a hybrid style to intone a song he wants the trainees to execute. While intoning the music, he mixes Pidgin with English as can be seen in the following extract: 'Gorr may mah...two, sing!' Though the language style he used is casual, the trainees recognised the melody and sang it in English. In fact, the Inspector wanted to say: 'God made man...two, sing!' but did not know the lyrics in English.

Still, Inspector Medou intoned a different song in Pidgin as extract 13 goes: 'I ghimemba', which was familiar with the trainees, who sang it in English. He did not know that the song in English was entitled 'I remember'. 
Extract 15 brings out another case of mixture where Sergeant Atangana combines English with Pidgin to address the trainees. In a comical way, he gave command in these words: 'On the spot, ma-a-ark tam! Lef-rize! Biafré! Lef-rize! Angléfu!' He continued: 'Le-e-e-e-f torn!' What Sergeant Atangana intended to say in English is this: 'On the spot, march! Left-right! Biafra! Left-right! Anglofools!'... 'On the right, once, halt!' ... "Turn left."

Extract 14 is a further case of hybrid language where Constable Akono gives orders to the trainees in various styles. The officer instructed the recruits in Pidgin as his predecessor did: 'Ever-y-y-y-y bodi!'...., 'Stresh out your hans sadwere! Make show you no tosh you voizin!'. He is expected to say: 'Everybody! Constable Akono ordered in a hoarse voice, 'Stretch out your hands sideways! Make sure you don't touch your neighbour."

Extract 16 portrays a situation of a pidginised speech, where Sergeant Atangana drills the new recruits in Pidgin as the words in italics in the table indicate. He wanted to say this: 'Jump each time your hands go up! Ordered Sergeant Atangana as he took over command the drill:

$$
\begin{aligned}
& \text { Up, sideways, down! } \\
& \text { Up, sideways, down! } \\
& \text { Up, sideways, down! }
\end{aligned}
$$

\section{$>$ English $\rightarrow$ Pidgin $\rightarrow$ French patterns}

A single case of English-Pidgin-French language cross was identified in the book studied.

Table5. Code-mixing: English-Pidgin $\rightarrow$ French patterns

\begin{tabular}{|l|l|}
\hline Number & Extract \\
\hline 17 & $\begin{array}{l}\text { 'By the lef, ma-a-ark tam!' barked out Constable Akono. He raised his kepi and swept his left } \\
\text { palm across his gleaming baldhead. As the recruits marked time, he chanted: 'Lef-rize! Un deux! } \\
\text { Lef-rize! Un-deux!' A few moments afterwards, he ordered: 'By the lef, forwa-a-ard ma-a-arsh! } \\
\text { Lef-rize! Un-deux! Lef-rize! Salopa!' (p.6) }\end{array}$ \\
\hline
\end{tabular}

It turned out from Table 5 that Constable Akono mixes three codes in his train of speech. He starts the speech in English with 'By the...' then proceeds with Pidgin in these words: '...lef, ma-a-ark tam!' In another stretch, he mixes pidgin with French: 'Lef-rize! Un deux! Lef-rize! Un-deux! [...] 'By the lef, forwa-a-ard ma-a-arsh! Lef-rize! Un-deux! Lef-rize! Salopa!' The police officer intended to say these words: 'By the left, march!" [...] "Left - right! Un deux! Left-right! Un deux!.” [...] "By the left, forward, march! Left right! Un deux! Left-right! Salopard!"

\section{$>$ English $\rightarrow$ Bafut language patterns}

Bafut language features also appeared in dialogic conversations.

Table6. English $\rightarrow$ Bafut language patterns

\begin{tabular}{|l|l|}
\hline Number & \multicolumn{1}{|c|}{ Extracts } \\
\hline 18 & $\begin{array}{l}\text { "Could he ever remember all of these nevers? He wondered how he would express himself when } \\
\text { distributing the parcels his parents had wrapped for various relatives. The most he knew in } \\
\text { Menemo was: 'Good morning - A fe no' } h \text { ! 'It's fine - Ze bong!' 'He is in the house - Iwo nga } \\
n e b ! \text { ' and 'Good night - Ti sis oh!' (p.62) }\end{array}$ \\
\hline 19 & $\begin{array}{l}\text { 'Fascinating!' Tebene chuckled. } \\
\text { 'Our parents teach us that every leaf is a remedy and every sound of nature is a message,' } \\
\text { Bi continued to intrigue Tebene. 'For instance, a woman who intends to go to the farm early } \\
\text { wakes up before the cuckoo bird sings its "tibid tuut-tuut" chorus. This is because in the morning } \\
\text { we hear 'tibid tuut-tuut" between } 4 \text { and } 5 \text { o'clock. There is also the clock bird, but this one sings } \\
\text { around } 6 \text { o'clock to wake up lazy workers." } \\
\text { 'Amazing!' Tebene asked in disbelief. } \\
\text { 'The cuckoo bird will indicate it to you as you set out or get near to your destination. The cuckoo } \\
\text { bird has three indicative songs. If it sings over and over: "Soh-bom"! "Soh-bom"! the first sound } \\
\text { high and the second one low, meaning: early egg, then the person is at home, or you will meet } \\
\text { with luck. When it sings: "mukako khe wu"? in short spaced out intervals, meaning: do you have } \\
\text { juggers in the feet? The phrase is urging you to hurry up so as to catch up with the person, or that } \\
\text { if you hurry you will be fortunate. And when it sings: "ejig tichu' kuu-kuu”! in a long repetitive } \\
\text { song, meaning: a person that eats without gargling the teeth, then it is indicating that the person is }\end{array}$ \\
\hline
\end{tabular}



Protus

\begin{tabular}{|l|c|}
\hline & not at home, but if you hurry you may be lucky.' (p.138) \\
\hline 20 & 'Are you Bafut people?' Adama asked. \\
& 'Yes,' Bi answered, looking at Tebene, \\
& 'Abe-fu'u!' Adama greeted in the Bafut language. \\
& 'No. It is $O$ shi'-me!' Sadatu corrected. (p.172) \\
\hline
\end{tabular}

It turns out in Table 6 that the narrator in extract 18 inserts some Bafut clauses in the narrative process. They are: 'A fe no'h!', ze bong!', 'Iwo nga neb!' and ' $t$ is sis oh!' which respectively mean 'good morning', it is fine, 'he is in the house' and 'good night' as the writer explained it.

Again, the narrator in extract 19 used Bafut language to discuss the meaning of four bird sounds in Bafut culture. He talked of the "tibid tuut-tuut" chorus, the "Soh-bom"! "Soh-bom", the "mukako khe $w u$ " and the "ejig tichu' kuu-kuu"! The first sound refers to the song the cukoo bird sings between 4 and 5 o'clock. The second cuckoo bird song means 'early egg'. The third signifies 'Do you have juggers in the feet?' and the last stands for 'a person who eats without gargling the teeth, then it is indicating that the person is not at home, but if you hurry you may be lucky.'

Extract 20 is a bilingual conversation which involves three characters who interact both in English and Bafut. Adama asked $\mathrm{Bi}$ and Tebene, who come from Yaounde, if they were from Bafut and $\mathrm{Bi}$ confirmed that. Thus, Adama greeted them in Bafut language in these words: 'Abe-fu'u!' but she was challenged by Sadatu who opined that it was poorly said and argued that it should be said: ' $O$ shi'$m e !$ ', which means 'How do you do?'.

\section{English $\rightarrow$ Fulfulde Patterns}

A single case was singled out of Protus novel as showcased by Table 7 which follows:

Table7. Code-mixing: English $\rightarrow$ Fulfulde patterns

\begin{tabular}{|l|l|}
\hline Number & Extract \\
\hline 21 & $\begin{array}{l}\text { So Jawugel was delighted. "I love to visit my dear old Granny!" he said. } \\
\text { So Jawugel went singing and dancing across the hill. "Allo Granny, mi don wara!" He was } \\
\text { singing about his grandmother!" (p.175) }\end{array}$ \\
\hline
\end{tabular}

Jawugel in extract 21 is having a phone conversation with his grandmother during which he uses both English and Fulfulde to converse. He starts the conversation in English with: "Allo Granny', then switches to Fulfulde 'mi don wara', to tell his that he is coming soon. This expression occurs four times in the novel.

\section{English $\rightarrow$ French Pattern}

A single case was singled out of the book.

Table8. English-French pattern

\begin{tabular}{|l|l|}
\hline Number & Extract \\
\hline 22 & 'Where is the Fon?' the police boss barked out impatiently. \\
& The palace attendants who stood nearby, holding their hands behind, said that they did not know \\
where the Fon was. & 'Did Mbeh go out?, Assi asked. \\
'We have only just entered the palace ahead of you.' Another old man said. 'How would we \\
know if he went out or not?' His mates grew irritated and began to question the strangers' right to \\
interrogate them as if they were children. \\
'Don't you have respect for this grey hair?' Chinga asked. \\
'Let the hair be green!' Agwe spat out losing his temper. 'Arrest them, Monsieur le \\
Commissaire!' (p.224).
\end{tabular}

Table 8 shows that French is invited in the exchange between the elders of the palace with Inspector Assi and Mr Agwe, the superintendent of police as demonstrated by extract 22 above. In fact, the Superintendent of police called Agwe went along with Officer Assi to the palace to meet the Fon. As they reached the palace, they could not get the Fon. The elders claimed they did not know where he was. One of them named Chinga got irritated after many questions and began to question the strangers' rights to interrogate them. The police boss went out of his temper and answered back arrogantly. Officer Assi then asked the Superintendent of police concurrently in English and French to arrest them as follows: 'Arrest them, Monsieur le Commissaire!'. 'Monsieur le Commissaire' in English stands for 'Mr the Superintendent of police.' 
Code Choice in Cameroon Creative Writing in English: A Case Study of The Immortal Seed by Tah Protus

\subsubsection{Borrowing}

Lexical borrowing is another code-mixing technique highlighted in the Immortal Seed. The narrator inserted Pidgin, French, Bafut and Spanish lexemes in the discourse during the narrative process. Those lexical items are presented in tables followed by the number of occurrences, the meaning and the register they pertain to.

\section{Pidgin English Lexemes}

Virtually nineteen instances of Pidgin English lexical words were sorted out from the book as presented in Table 1 below:

Table9. Pidgin English lexemes

\begin{tabular}{|c|c|c|c|c|c|}
\hline $\mathbf{N}^{\circ}$ & Lexemes & Occurrences & Meaning & Register & Total \\
\hline 1 & bobolo & 1 & cassava sticks & Food & \multirow[t]{3}{*}{$05(15.15 \%)$} \\
\hline 2 & garri & 1 & ground and dry cassava & Food & \\
\hline 3 & maize koki & 3 & maize pudding & food & \\
\hline 4 & njangi & 1 & meeting where people pledge money & finances & $01(3.03 \%)$ \\
\hline 5 & banga & 5 & Indian hem & drug & $05(15.15 \%)$ \\
\hline 6 & mbere-khaki & 3 & policeman & job & $03(09.09 \%)$ \\
\hline 7 & ngambe-man & 1 & wizard & Witchcraft & \multirow[t]{5}{*}{$08(24.24 \%)$} \\
\hline 8 & ngambe & 1 & tradition /spirits & witchcraft & \\
\hline 9 & Nyongo & 1 & sect & witchcraft & \\
\hline 10 & Nyongo-house & 4 & sect house & witchcraft & \\
\hline 11 & Nyongo man & 1 & sectarian & witchcraft & \\
\hline 12 & fey-men & 1 & crooks & criminals & $01(3.03 \%)$ \\
\hline 13 & chinda & 3 & notable & kingship & $03(9.09 \%)$ \\
\hline 14 & bakala & 2 & hairdressing with four braids & hairstyle & $02(6.06 \%)$ \\
\hline 15 & okro & 1 & okra & vegetables & $01(3.03 \%)$ \\
\hline 16 & $k a b a$ & 1 & traditional attire & clothes & \multirow[t]{3}{*}{$03(09.09 \%)$} \\
\hline 17 & Okrika & 1 & cheap imported dresses & clothes & \\
\hline 18 & agwada & 1 & Hausa traditional attire & clothes & \\
\hline 19 & Kongo meat & 1 & snail & reptile & $01(3.03 \%)$ \\
\hline \multicolumn{2}{|c|}{ Total } & 33 & & & $33(100 \%)$ \\
\hline
\end{tabular}

Table 9, which exhibits Pidgin English lexemes, shows that witchcraft lexical words $(24.24 \%)$ dominated over lexis associated with food $(15.15 \%)$, drug (15.15\%), clothes $(09.09 \%)$, job $(09.09 \%)$, kingship $(9.09 \%)$, finances $(3.03 \%)$, hairstyle $(6.06 \%)$, vegetables $(3.03 \%)$ and reptile $(3.03 \%)$.

\section{$>$ Bafut lexemes}

Twenty three direct loans from Bafut language were inserted in Protus text as summarised in Table 10 which follows:

Table10. Bafut lexemes

\begin{tabular}{|c|c|c|c|c|c|}
\hline $\mathbf{N}^{\circ}$ & Lexemes & Occurrences & Meaning & Register & Total \\
\hline 1 & Kenja & 4 & $\begin{array}{l}\text { Basket made with palm trees } \\
\text { used to go to farm }\end{array}$ & Traditional tool & $04(2.70 \%)$ \\
\hline 2 & Tad & 18 & The clan market & culture & \multirow[t]{2}{*}{$28(18.91 \%)$} \\
\hline 3 & Ayene & 10 & Let it be so & culture & \\
\hline 4 & eghem & 6 & Family place of worship & divinity & \multirow[t]{2}{*}{$09(6.08 \%)$} \\
\hline 5 & Ateremba & 3 & goddess & divinity & \\
\hline 6 & Mbeh & 38 & Fon & kingship & \multirow[t]{4}{*}{$78(52.70 \%)$} \\
\hline 7 & Teken & 15 & $\begin{array}{llll}\begin{array}{l}\text { Group of elders who take } \\
\text { decisions in the clan }\end{array} & & \\
\end{array}$ & Kingship & \\
\hline 8 & gwe & 4 & The fon's foot soldiers/guards & Kingship & \\
\hline 9 & Megwe & 21 & The fon's foot soldiers/guards & Kingship & \\
\hline 10 & Mukonge & 1 & Traditional dance & dance & $01(0.67 \%)$ \\
\hline 11 & mban & 13 & House/family place of worship & architecture & $13(8.78 \%)$ \\
\hline 12 & Mbirike & 1 & Herbal oil & oil & $01(0.67 \%)$ \\
\hline 13 & eteb & 1 & Egusi pudding & food & \multirow{2}{*}{$06(4.05 \%)$} \\
\hline 14 & mbakah of & 1 & A basket of cocoyams & food & \\
\hline
\end{tabular}


Code Choice in Cameroon Creative Writing in English: A Case Study of The Immortal Seed by Tah Protus

\begin{tabular}{|c|c|c|c|c|c|}
\hline & $\begin{array}{l}\text { nang pon- } \\
\text { pon }\end{array}$ & & & & \\
\hline 15 & $\begin{array}{l}\text { mbakah of } \\
\text { achu }\end{array}$ & 1 & A basket of $a c h u$ & food & \\
\hline 16 & $\begin{array}{l}\text { mbakah of } \\
\text { corn-fufu }\end{array}$ & 1 & A basket of fufu corn & food & \\
\hline 17 & $\begin{array}{l}\text { ndong-bun } \\
\text { yam }\end{array}$ & 1 & Variety of yam & food & \\
\hline 18 & $\begin{array}{l}\text { colocashia } \\
\text { coco-yams }\end{array}$ & 1 & A variety of cocoyams & food & \\
\hline 19 & Nyam! & 1 & $\begin{array}{l}\text { Cow /Animal! (used here as an } \\
\text { insult) }\end{array}$ & offence & $01(0.67 \%)$ \\
\hline 20 & Ko'oh & 1 & The day after the clan market & calendar & $01(0.67 \%)$ \\
\hline 21 & togho'oh & 3 & Traditional wear/attire & clothes & $03(2.02 \%)$ \\
\hline 22 & inohrr & 1 & Palm wine & drink & $01(0.67 \%)$ \\
\hline 23 & Isamni & 2 & A type of herb & vegetation & $02(1.35 \%)$ \\
\hline \multicolumn{2}{|c|}{ Total } & 148 & & & $148(100 \%)$ \\
\hline
\end{tabular}

In accordance with Table 10 above, the lexical field of kingship (52.70\%) prevailed over cultural lexemes $(18.91 \%)$, divinity $(6.08 \%)$, food $(4.05 \%)$, traditional tool $(2.70 \%)$, architecture $(8.78 \%)$, oil $(0.67 \%)$, offence $(0.67 \%)$, calendar $(0.67 \%)$, clothes $(0.67 \%)$, drink $(0.67 \%)$, and vegetation $(1.35 \%)$.

\section{$>$ French loans}

Three lexemes were occasionally used in The Immortal Seed. Table 3 below displays them with their meaning. They are direct loans from French language.

Table11. French loans

\begin{tabular}{|l|l|l|l|}
\hline $\mathbf{N}^{\circ}$ & Items & Occurences & Meaning \\
\hline 1 & camouflé tracksuit & 1 & Camouflaged tracksuit \\
\hline 2 & Coup de grạce & 1 & Death blow \\
\hline 3 & tête-à- tête & 1 & Face-to-face \\
\hline
\end{tabular}

\section{$>$ Spanish Loan}

In extract 23, the writer inserted a Spanish morpheme 'pecunia' which refers to money as follows: 'Why could she not learn to control and resist that urge for pecunia, as Ngome called money?'

\section{$>$ Calque or Loan Translation}

Calque is a linguistic term for the direct or one-to-one translation of the morphemic elements of a foreign word or phrase into the equivalent morphemes in another language. In other words, it is a literal transfer of lexical, morphological, syntactic and semantic elements of a source language into a target language. A lot of Bafut sayings were spread through The Immortal Seed. Those words of wisdom, full of meaning are presented in a table followed by their intended meaning. Seventeen of them were selected.

Table13. Calque

\begin{tabular}{|l|l|l|}
\hline Number & Calque & Meaning \\
\hline 24 & $\begin{array}{l}\text { 'Must the sentinel-monkey wait for the hunter's } \\
\text { gun to fire before it warns its brethren that it saw } \\
\text { the hunter raise the gun?' (p.84) }\end{array}$ & $\begin{array}{l}\text { Must someone let his brothers and sisters fall } \\
\text { in danger and tell them later that they foresee } \\
\text { it? }\end{array}$ \\
\hline 25 & $\begin{array}{l}\text { 'Tebo should not behave like the bamboo } \\
\text { beetle,' Asoh went on 'which ate through the } \\
\text { bamboo, believing that it was only a bamboo but } \\
\text { when it came out on the opposite side, it realised } \\
\text { that it had destroyed its own home.' (p.84) }\end{array}$ & $\begin{array}{l}\text { Tebo is compared to the bamboo beetle which } \\
\text { destroys its home unknowingly exposing itself } \\
\text { to danger. }\end{array}$ \\
\hline 26 & $\begin{array}{l}\text { 'Can a bullet wound a baby monkey in the } \\
\text { womb without touching the mother?' he asked.' } \\
\text { (p.84) }\end{array}$ & $\begin{array}{l}\text { Can a baby be attained without her mother } \\
\text { being affected? }\end{array}$ \\
\hline 27 & $\begin{array}{l}\text { 'Asoh, you are digging into a snake's hole with } \\
\text { bear hands.' }\end{array}$ & $\begin{array}{l}\text { The speaker is cautioning Asoh against his } \\
\text { imprudence. }\end{array}$ \\
\hline
\end{tabular}




\begin{tabular}{|c|c|c|}
\hline 28 & $\begin{array}{l}\text { 'My friend, you're only trying to hide behind a } \\
\text { broom stick,' Asoh retorted with a giggle. } \\
\text { 'Scratch the buttock that is itching!' (p.84) }\end{array}$ & $\begin{array}{l}\text { Asoh is advising his friend not to be ashamed } \\
\text { to talk of his problem openly. }\end{array}$ \\
\hline 29 & $\begin{array}{l}\text { 'Did the elders not say that one should not play } \\
\text { with a pig because it would surely rub you with } \\
\text { mud even when you are dressed for a festival?' } \\
\text { (p.85) }\end{array}$ & $\begin{array}{l}\text { The elders advise people to be cautious. They } \\
\text { should not play with danger thinking that they } \\
\text { are wise. }\end{array}$ \\
\hline 30 & $\begin{array}{l}\text { 'He was one who believed that if a calabash full } \\
\text { of new wine was not given a vent, it could } \\
\text { explode.' (p.85) }\end{array}$ & $\begin{array}{l}\text { It is the belief that when there is a crucial } \\
\text { problem it should be solved before it worsens. }\end{array}$ \\
\hline 31 & $\begin{array}{l}\text { 'Can two waterfalls hear each other?, he asked.' } \\
\text { (p.85) }\end{array}$ & Can two people talk at the same time? \\
\hline 32 & $\begin{array}{l}\text { 'Our ancestor says that the hand that lingers } \\
\text { around the anus touches faeces'. (p.85) }\end{array}$ & He who plays with fire burns himself. \\
\hline 33 & $\begin{array}{l}\text { 'He who hides faeces between legs shall be } \\
\text { betrayed by the fly.' (p. } 86 \text { ) }\end{array}$ & Concealment is transient. \\
\hline 34 & $\begin{array}{l}\text { 'Our ancestor say' Ben-Tasi continued, 'a man } \\
\text { does not incise an abscess between his thighs in } \\
\text { front of women and children.' (p.88) }\end{array}$ & $\begin{array}{l}\text { Serious matters are handled behind closed } \\
\text { doors. }\end{array}$ \\
\hline 35 & $\begin{array}{l}\text { 'Our ancestors say that no one carries a log of } \\
\text { wood with fire on it in his fibre bag.' (p.88) }\end{array}$ & A word of wisdom to careless people. \\
\hline 36 & $\begin{array}{l}\text { 'The stream lost his way because there was no } \\
\text { one to direct it. Should our family stray into the } \\
\text { bush with you and me still able to see even in } \\
\text { the dark?' (p.89) }\end{array}$ & $\begin{array}{l}\text { People fail in life because they are not } \\
\text { advised. You cannot see a danger from afar } \\
\text { and allow your people to die when you can } \\
\text { save them. }\end{array}$ \\
\hline 37 & $\begin{array}{l}\text { 'Now we have two matters in our hands. We } \\
\text { shall not spend the night repairing the bed while } \\
\text { there is sleep in our eyes.' (p.89) }\end{array}$ & $\begin{array}{l}\text { The speaker is advising his peers to sort out } \\
\text { the urgent matter submitted to them without } \\
\text { delay. }\end{array}$ \\
\hline 38 & $\begin{array}{l}\text { 'He had roasted his palms for too long trying to } \\
\text { pull his brother's share of meat from the fire. } \\
\text { And now, his clothes were about to catch fire } \\
\text { because he was helping a brother who did not } \\
\text { seem to need the meat.' (p.89) }\end{array}$ & $\begin{array}{l}\text { A piece of advice to people who worry about } \\
\text { other people's matter when the very } \\
\text { concerned do not care about themselves. }\end{array}$ \\
\hline 39 & $\begin{array}{l}\text { A man who drowns in a river after his brothers } \\
\text { have thrown him the rescue hope has no one but } \\
\text { himself to blame.' (p.89) }\end{array}$ & $\begin{array}{l}\text { If help is given to someone and they refuse it, } \\
\text { they have themselves to blame. }\end{array}$ \\
\hline 40 & $\begin{array}{l}\text { 'My fathers,' he began, 'when a man sees thick } \\
\text { smoke on a neighbour's roof top in the dry } \\
\text { season, should he wait for the flames to appear } \\
\text { before he raises an alarm?' (p.90) }\end{array}$ & $\begin{array}{l}\text { Distressed people should be relieved before } \\
\text { the situation gets worse. }\end{array}$ \\
\hline
\end{tabular}

\subsection{Variation in Style}

Variation in style in Protus novel concerns the choice of a substandard or casual style used by some characters.

\subsubsection{Substandard choice}

In his discursive strategy, the writer also made substandard choices or casual styles to respond to specific needs.

Table13. Substandard choice

\begin{tabular}{|c|c|}
\hline Number & Extracts \\
\hline 41 & $\begin{array}{l}\text { Sergeant Atangana handed command over to Superintendent Essono who had an Americanised } \\
\text { attitude of the English Language. } \\
\text { 'Attention! Henz up! Down!' Superintendent Essono began. The recruits obeyed more } \\
\text { keenly. } \\
\text { 'Henz into ze packits p-u-ut! Essono ordered. The recruits mechanically thrust their hands } \\
\text { into the two and only pockets on their training trousers. } \\
\text { 'Everyssings } o \text { - } u \text {-t! Superintendent Essono snarled. } \\
\text { The recruits brought their hands out from their pockets, some with handkerchiefs and others } \\
\text { with bits of fast foods bought along the way, but everyone with some money. }\end{array}$ \\
\hline
\end{tabular}




\begin{tabular}{|l|l|}
\hline & $\begin{array}{l}\text { 'To ze officers, g-i-ve!' Superintendent Essono howled. 'Officers on duty, move round and } \\
\text { collect everyssings!' Then turning to the recruits, he warned, 'Woe betide you if ze officers find } \\
\text { zat you lef enyssings whatsoever in your pakits! Keep your henz stresh-out till I order you } \\
\text { bring'em down!' (p.8-9) }\end{array}$ \\
\hline 42 & $\begin{array}{l}\text { 'Recruits! Announced Superintendent Essono. 'From zis simpol operation, you can see how } \\
\text { dizonest you are. For zis reason, you shall lose all zis mani. As ze citizens about to be trained for } \\
\text { human lives, it is obligatoire for you to be honest and obedient at all ze times. Ze lesson one, } \\
\text { repeat after me: A police officer must alwez be } z e \text { most honest citizen in } z e \text { country!' (p.9) }\end{array}$ \\
\hline 43 & $\begin{array}{l}\text { Dieres Menyan, } \\
\text { not the oda yousless girl dat evribody is tokin abawt. Did I kari wud to her company? I was bon } \\
\text { to mari you. Only God can sepret us. If our perents try to stop our lof then I shall tek away my } \\
\text { live. Mit me in the haus this evenin asun as your perents go to slip. We have many ting to diskos } \\
\text { bifor the reconsilisasion day. I wan pipel to now you as my waif on that day. Plis, do not main } \\
\text { the storis that piple are tolkin abawt me and any oda girl. You are the one I shall mari. If you fell } \\
\text { me then you will only have my ded body to confes to. }\end{array}$ \\
\hline
\end{tabular}

Table 13 indicates that the narrator speech is interspersed with casual talks. Oral communication features are introduced in writing. The writer narrates in English a scene where Sergeant Atangana shows off his competence in American English as follows: 'Attention! Henz up! Down!'... 'Henz into ze packits p-u-ut!' ... 'Everyssings o-u-t!'... 'To ze officers, g-i-ve!'...'ze' 'zat'... 'lef enyssings'... 'henz stresh-out'... 'bring 'em', the character oddly pronounced.

Similarly, superintendent Essono in extract 42 adopts the same americanised attitude, where he mingles the British style with the American pronunciation system. The pronunciation style of the words 'zis people'... 'dizhonest'... 'zis'... 'ze'... 'alwez' are snobbish. Besides, the speaker added the French word 'obligatoire' in his speech.

However, extract 43 highlights a case of low competence in English, where Tembi is unable to write properly a letter officer Assi dictated to him. The correct form of the letter reads:

\section{Dear Menyan,}

Do not be surprised by this letter. It is love that makes me write. It is you I wish to marry now, not the other useless girl that everybody is talking about. Did I carry wood to her company? I was born to marry you. Only God can separate us. If our parents try to stop our love, then I shall take away my life. Meet me in the house this evening as soon as your parents go to sleep. We have many things to discuss before the reconciliation day. I want people to know you as my wife on that day. Please, do not mind the stories that people are talking about me and any other girl. You are the one I shall marry. If you fail me then you will only have my dead body to confess to.

\subsection{Paralinguistic functions of code choice in The Immortal Seed}

There are many reasons for which Tah Protus alternates or blends codes in the development of his story. Different linguistic selections were made to achieve the following functions:

\section{a) Sarcastic irony and humour markedness}

Tah Protus designed characters who pidginise, frenchify and americanise English language. By the way, the Mutengene Federal Police Academy mentioned in the novel, where new recruits in the police are given training, is found in the South West region of Cameroon, with English as the domineering official language. Constable Akono (extract 1), Sergeant Atangana (extract 2), Superintendant Essono (extract 12), or Inspector Medou (extract 13) French-speaking police officials, because they did not have a good command of English language, shamelessly mixed English with Pidgin, Pidgin with French or adopt an American pronunciation style while communicating with the trainees. The narrator purposefully ridicules them for the reason that, serving in an English-speaking region, those top police officials are supposed to be proficient in English language to communicative in their workplace. These police officials in their interactions instead use a casual style to survive in English. The mixing of code by these top police officials caused the recruits to giggle when they were given orders: "Amidst giggling and stifled yawns, the recruits tried as best they could to execute the orders.", the narrator reported (p.6). Superintendent Essono did not tolerate that the recruits mock at him and he vehemently ordered: "No more giggling!", the narrator said. 
Additionally, the writer mocks at Akwen who prays in a garbled and confused language, a prayer style proper to revival churches who claim to pray in 'tongue' (extract 11).

\section{b) Equivalence, loyalty, ethnicity and solidarity markedness}

The writer used intra-sentential code-switching or code-mixing where he inserted a wealth of lexical items (Table 6), utterances (extract 9, extract 10), songs (extract 8) from Bafut language and Pidgin English lexemes (Table 9) in sentences for equivalence constraints, solidarity and ethnicity. As there was no formal correspondence of Bafut lexemes in English, the writer remained loyal to his culture. A direct translation of those items in English would remove the intrinsic value of those words. The writer's loyalty to his culture also aims at avoiding social distance with his audience and thereby reveals his group membership. Calque structures (Table 13), widespread in the book, betray the novelist origin.

\section{c) Explanation and clarity markedness}

The narrator used Bafut expressions in the narrative process and to be explicit, he explained them to the reader for clarity. For instance, he explained to readers greetings in Bafut culture, as shown by extract 18 and extract 20.

In addition, he identified four bird sounds whose meanings are recalled in extract 19: 'The cuckoo bird has three indicative songs. If it sings over and over: "Soh-bom"! "Soh-bom"! the first sound high and the second one low, meaning: early egg, then the person is at home, or you will meet with luck. When it sings: "mukako khe wu"? in short spaced out intervals, meaning: do you have juggers in the feet? The phrase is urging you to hurry up so as to catch up with the person, or that if you hurry you will be fortunate. And when it sings: "ejig tichu' kuu-kuu”! in a long repetitive song, meaning: a person that eats without gargling the teeth, then it is indicating that the person is not at home, but if you hurry you may be lucky.' (p.138)

\section{d) Class markedness}

The choice of a substandard style (extract 42) in the book of Tah Protus aimed at revealing the low level of education of Tembi, a villager who did not go further with his education, a good reason to be unable to write an informal letter in English. The letter crops up with mistakes. It filters out of the letter the character wrote, that he is lowly educated.

\section{e) Imitation, snobbism and multilingual competence markedness}

The choice of Fulfulde, French and Spanish codes by Protus is not done haphazardly. Though he is an English-speaking Cameroonian, the writer includes Fulfulde expressions in conversations as shown in extract 5, extract 6 , extract 7 and extract 21 to boast of his multilingual competence. He also inserted French words (extract 22) in utterances or borrowed them (Table11) for snobbism. The use of the Spanish lexeme in the book known as 'pecunia' is done to imitate the way Ngome called money as the writer explained it. Implicitly, the writer wants to sound big and knowledgeable.

\subsection{Proteus Concerns}

Tah Protus, behind the rich and exceptional language twist perceptible in his literature book, aimed at denouncing language problem and intelligibility in British Cameroon State institutions, stereotypes and stigmatization. Not only did the writer revolt in front of the ill-treatment of English Cameroonians but he also promoted multiculturalism, living together and social integration.

\subsubsection{The language question in British Cameroon State institutions}

The writer deliberately made Superintendent Essono, Constable Akono, and Inspector Medou speak poor English, to castigate the Cameroon government attitude who appoint monolingual francophone civil servants in English-speaking regions. Unable to communicate fluently in English, these officials resort to broken English, which sometimes, are communicatively misleading and disconcerting. The issue is acute so much so that trainers themselves express their worry wondering 'what a linguistic ordeal their training could be.' (p.6) Further, 'they wondered why all their teachers appeared to be French-speaking while they, students, were English-speaking. Were there no English speaking police officers who could train them? They pondered.' (p.9) The language problem raised in British Cameroon Sate institutions is one of the causes of the Anglophone crisis which has been rocking the English-speaking regions of Cameroon since October 2016. 


\subsubsection{Stereotypes and stigmatisation}

Sergeant Atangana stigmatises English-speaking students tagging them as Biafré (Biafra) and Angléfu (anglofools) (p.7). In the same vein, Constable Akono treats them as 'salopa' (swine) (p.6). Englishspeaking Cameroonians since long have been perceived by their French-speaking counterparts as Biafra and anglofools. These stereotypes and offensive images make English-speaking Cameroonians look themselves as outcast or second class citizens, hence the desire to part and form an autonomous State nursed by Anglophone separatists. The creation of the 'Republic of Ambazonia' nursed by separatists stems from the feeling of marginalization, discrimination and rejection they are confronted with. Tah Protus designed the characters above-mentioned and lent them words to express the realities of the Cameroon society.

\subsubsection{Multilingualism and multiculturalism}

Tah Protus, far from being a separatist, instead promotes multiculturalism. Cameroon is a bilingual and multicultural nation. The writer has interwoven English with indigenous languages (Bafut dialect), lingua francas (Pidgin English, Fulfulde) and foreign languages (French, Spanish) in The Immortal Seed to encourage multiliteracy. Readers learnt about songs (extract 5), greetings (extract 18), the meaning of birds' songs (extract 19) in Bafut culture. He taught readers some factual elements of Bafut culture related to kinship, divinity, food, traditional tool, architecture, offence, calendar, clothes and vegetation. He graced his writing with Bafut aphoristic sayings through the phenomenon of calque.

\subsubsection{Pacific coexistence, living together and social integration}

Despite language differences between the Mbororos and the Medik people in the novel analysed, the Fon through the writer's voice enjoin both community to cohabitate peacefully and to enjoy the same rights. He urges the Medik to 'embrace their Mbororo neighbours and live with them as brothers and sisters. Dik will not complete without its Mbororo community.' (p.244). Through these appeasing words, the writer promotes pacific coexistence, living together and social integration. The use of Fulfulde by the Mbororo community in extract 6 confirms their wish to commune with their counterparts.

\section{CONCLUSION}

The purpose of this study was to explore types of code choice in The Immortal Seed. It also looked into roles of the linguistic choices made and the writers' concerns underlying the writing technique employed. Data collected were chiefly corpus-based and the analysis of data transpired from Sumarsono (2009) and Myers-Scotton $(1993,1998)$ theoretical paradigms. The findings revealed in the story development of his novel that, Tah Protus interwove code-switching, code-mixing, calque and informal style and this helped him to negotiate many sociolinguistic relationships such as sarcasm, humour, equivalence, loyalty, ethnicity, solidarity, explanation, clarity, class, imitation, snobbism and multilingual competence. The writer, through the language choices effected, raised the language question in the British Cameroon Sate institutions including the social stigma the people of that area suffer. Nevertheless, he promotes multiculturalism, pacific coexistence, living together and social integration. Multilingual choices operated by the novelist reflect the linguistic landscape of his country Cameroon and reveal the writer's dexterity and flexibility in the handling of literary and linguistic complex issues.

\section{SUGGESTIONS FOR FURTHER RESEARCH}

This research study has shown how the use of code-switching and code-mixing has contributed to negotiate differing relationships and above all to represent the complexities of the Cameroon society. Further investigations can be carried out in multiliteracy in elementary education in Cameroon.

\section{REFERENCES}

[1] Al-Khatib, H. (2003). Dialect alternation among Arabic and English youth bilinguals: Reflecting or constructing social realities? In Worldwide Journal of Bilingual Education and Bilingualism, Vol 1, N ${ }^{\circ}$, pp-409-422.

[2] Auer, P. (ed.). (1998). Code-switching in conversation: language, interaction and identity. London: Routledge. 
[3] Bullock, B. E. and Toribio, A. J. (eds) (2009) The Cambridge Handbook of Linguistic Codeswitching. Cambridge: Cambridge University Press.

[4] Dumanig, F. (2007). Analysis on the language choice and marital typology of South-East Asian couples. Paper Presented at the 2nd Singapore Graduate Forum on Southeast Asian Studies. Singapore.

[5] Genesee, F. (1982). The social psychological significance of code-switching in cross-cultural communication. In Journal of language and social psychology, Vol.1, º1, pp.1-27.

[6] Halliday, M.A.K. (1989). Spoken and written language. Oxford: Oxford University Press.

[7] Holmes, J. (2013). An introduction to sociolinguistics (4 ${ }^{\text {th }}$ Ed.). London: Routledge.

[8] Kouega, J.P. \& Aseh, M. (2017). Pidgin in creative works in English in Cameroon. In Sustainable Multilingualism | 10/2017http://dx.doi.org/10.1515/sm-2017-0005.

[9] Muysken, P. (2000). Bilingual speech: A typology of code-mixing. Cambridge University Press.

[10] Myers-Scotton, C. (1993). Social motivations for code-switching: evidence from Africa. Oxford, Uk: Clarendon Press.

[11] Myers-Scotton, C. (1998). A theoretical introduction to the markedness model. In C. Myers- Scotton (Ed.), Codes and consequences: choosing linguistic varieties (pp.18-40). New York: Oxford University Press.

[12] Romaine, S. (1992). Bilingualism. Blackwell Publishers: Cambridge.

[13] Sokeng, P. S. C. (2018). Code Switching “as a Bilateral Tool” in Cameroonian ESL/EFL Classrooms. In Journal of Education and Practice, Vol.9, No.12, pp.113-122.

[14] Suleiman, Y. (1999). Dialect and society in the Middle East and North Africa: studies in variation and identity. Richmond: Curzon Press.

[15] Sumarsono. 2009. Sosiolinguistik. Yogyakarta: Penerbit Sabda.

[16] Tah, P. (2015). The Immortal Seed. Cameroon: Ripple Publishers.

[17] Ukam, E.I. (2018). The choice of language for African creative writers. In English linguistic research, Vol.7, $\mathrm{N}^{\circ} 2$, pp.46-53.

[18] Wallwork, J. F. (1981). Language and People. London: Heinemann Educational Books.

[19] Wardhaugh, R. (2010). An introduction to sociolinguistics ( $6^{\text {th }}$ Ed.). UK: Wiley-Blackwell

[20] Wardhaugh, R. \& Fuller, J.M. (2015). An introduction to sociolinguistics (7 $7^{\text {th }}$ Ed.). Uk: Blackwell

[21] Yepdia, L. W. (2002). Code-switching in Achebe's No Longer at ease. Unpublished Maîtrise Thesis. University of Yaounde I.

\section{AUTHOR'S BIOGRAPHY}

Yepdia Leundjeu Walter, was born at Obout, Cameroon, in 1980. He obtained the B.A. degree in Bilingual Studies (English and French) from the University of Yaounde I, Cameroon, in 2002, and the Maîtrise, DEA and Ph.D. degrees in English Language from the University of Yaounde I, Cameroon, in 2004, 2007 and 2014, respectively. Further, he is holder of the Secondary and High School Teacher's Diploma in Bilingual Studies from ENS Yaounde in 2005. In 2020, he was recruited as lecturer of English language and linguistics at the University of Ngaoundere, in the faculty of Arts, Letters and Social Sciences, Department of English. His current research interests include sociolinguistics, creative writing and discourse analysis.

Citation: Yepdia Leundjeu Walter. "Code Choice in Cameroon Creative Writing in English: A Case Study of The Immortal Seed by Tah Protus" International Journal on Studies in English Language and Literature (IJSELL), vol 8, no. 12, 2020, pp. 14-32. doi: https://doi.org/10.20431/2347-3134.0812002.

Copyright: (1) 2020 Authors. This is an open-access article distributed under the terms of the Creative Commons Attribution License, which permits unrestricted use, distribution, and reproduction in any medium, provided the original author and source are credited. 